\title{
PEMERIKSAAN KADAR GULA, ASAM URAT DAN KOLESTEROL DARAH GRATIS UNTUK LANSIA DI KLINIK PRATAMA ASY SYIFA KOTA BENGKULU
}

\section{EXAMINATION OF GLUCOSE, URIC ACID, AND CHOLESTEROL'S BLOOD LEVEL AT KLINIK PRATAMA ASY SYIFA BENGKULU}

\author{
Oleh: \\ Lala Foresta dan Valentine Gunasari \\ Fakultas Kedokteran dan Ilmu Kesehatan Universitas Bengkulu \\ lalavalentine.gunasari76@gmail.com
}

\begin{abstract}
The increasing of age followed by the decreasing of cell function which causes organ weakness, physical deterioration, as well as the appearance of some disease especially degenerative diseases, such as the increasing level of the glucose, uric acid, and cholesterol in the blood. At the beginning, usually those diseasesdo not indicate definite symptomps, so they could be detected only if the complications and damages were appeared. Delayed diagnosing and providing adequate treatment could increases the risk of mortality, morbidity, and disability on elderly, so it is necessary to do routine and periodic examination of health on elderly to filter the onset of symptomps of the diseases. In this program we did the examination of blood level of glucose, uric acid, and cholesterol on elderly (> 60 years old) at Klinik Pratama Asy Syifa Kota Bengkulu to socialize the importance of routine and periodic health examination for early detection if comes the problem in examination, and the adequate treatment could be given as soon as possible.
\end{abstract}

Keywords: elderly, examination, blood glucose, uric acid, cholesterol

\section{PENDAHULUAN}

Seiring meningkatnya derajat kesehatan dan kesejahteraan penduduk, peningkatan usia harapan hidup (UHH) juga terjadi. Berdasarkan laporan Perserikatan Bangsa-Bangsa 2011, pada tahun 2000-2005, UHH adalah 66,4 tahun (dengan persentase populasi lansia tahun 2000 adalah 7,74\%). Angka tersebut diperkirakan akan meningkat pada tahun 20452050 menjadi 77,6 tahun (dengan persentase populasi lansia 28,68\%). Begitu pula dengan laporan Badan Pusat Statistik (BPS) terjadi peningkatan UHH. Pada tahun 2000 UHH di Indonesia adalah 64,5 tahun (dengan persentase populasi lansia 7,18\%). Angka ini meningkat menjadi 69,43 tahun pada tahun 2010 (dengan persentase populasi lansia $7,56 \%$ ) dan pada tahun 2011 menjadi 69,65 tahun dengan persentase populasi lansia adalah 7,56\% (Depkes, 2007). 
Pertambahan usia pada lansia mengiringi kemunduran fisik dan mental yang menimbulkan banyak konsekuensi. Pada lansia terjadi kemunduran sel-sel karena proses penuaan yang dapat berakibat pada kelemahan organ, kemunduran fisik, timbulnya berbagai macam penyakit di antaranya seperti peningkatan kadar gula darah, asam urat, dan kolesterol (Efendi dan Makhfudli, 2009). Perubahan ini seringkali tidak menimbulkan gejala yang jelas, sehingga baru diketahui saat sudah menyebabkan komplikasi dan kerusakan yang parah. Akibatnya terjadi peningkatan risiko disabilitas bahkan kematian. Untuk itu, sangatlah perlu dilakukan pemeriksaan kesehatan berkala pada lansia.

Lansia mulai mengalami penurunan fungsi fisiologis, yang dapat berimplikasi pada masalah kesehatan, terutama berupa penyakit-penyakit degeneratif. Penyakit degeneratif yang sering diderita oleh lansia di antaranya adalah Diabetes Mellitus, Huperuricemia, dan Hiperkolesterolemia. Sifat-sifat penyakit pada lansia tersebut perlu untuk dikenali agar tidak terlambat bahkan salah dalam menegakkan diagnosis, sehingga terapi dan tindakan lain yang mengikutinya segera dapat dilaksanakan. Diagnosis dan penatalaksanaan yang terlambat dan tidak tepat dapat meningkatkan risiko mortalitas, morbiditas, dan disabilitas pada penderitanya. Untuk itu perlu dilakukan pemeriksaan kesehatan secara rutin dan berkala pada lansia, misalnya dengan pemeriksaan seperti yang dilakukan pada kegiatan ini.

\section{Lansia}

Menurut pasal 1 ayat (2), (3), (4) UU No. 13 Tahun 1998 tentang kesehatan, dikatakan bahwa lansia (lanjut usia) adalah seseorang yang telah mencapai usia lebih dari 60 tahun (Darmojo, 2009).Sifat-sifat penyakit pada lansia perlu untuk dikenali agar tidak terlambat atau bahkan salah dalam menegakkan diagnosis, sehingga terapi dan tindakan lain yang mengikutinya segera dapat dilaksanakan. Hal ini akan menyangkut beberapa aspek, yaitu etiologi, diagnosis, dan perjalanan penyakit (Darmojo, 2009).

\section{Diabetes Mellitus}

Pada saat ini, sekitar 50\% lansia mengalami intoleransi glukosa dengan kadar gula darah puasa normal (Kane et al., 2009). Studi epidemiologi menunjukkan bahwa prevalensi Diabetes Mellitus (DM) maupun Gangguan Toleransi Glukosa (GTG) meningkat seiring dengan pertambahan usia, menetap sebelum akhirnya menurun. Dari data WHO didapatkan bahwa setelah mencapai usia 30 tahun, kadar glukosa darah akan naik 1-2 mg\%/tahun pada saat puasa dan akannaik sebesar 4,6-13 mg\%/tahun pada 2 jam setelah makan (Subramaniam, 2005).

Seiring dengan pertambahan usia, lansia mengalami kemunduran fisik dan mental yang menimbulkan banyak konsekuensi. Selain itu, kaum lansia juga mengalami masalah khusus yang memerlukan perhatian antara lain lebih rentan terhadap komplikasi makrovaskular maupun mikrovaskular dari DM dan adanya sindroma geriatri (Rochmah, 2007). 
Seiring dengan proses penuaan, semakin banyak lansia yang berisiko terhadap terjadinya DM, sehingga sekarang dikenal istilah prediabetes. Prediabetes merupakan kondisi tingginya gula darah puasa $(\mathrm{GDP}=100-125 \mathrm{mg} / \mathrm{dL})$ atau gangguan toleransi glukosa (kadar gula darah 140-199 mg/dL, 2 jam setelah pembebanan 75 g glukosa). Modifikasi gaya hidup mencakup menjaga pola makan yang baik, olah raga dan penurunan berat badan dapat memperlambat perkembangan prediabetes menjadi DM. Bila kadar gula darah mencapai $\geq 200 \mathrm{mg} / \mathrm{dL}$, maka pasien ini masuk dalam kelas DM (Rochmah, 2007). Gangguan metabolisme karbohidrat pada lansia meliputi 3 hal, yaitu resistensi insulin, hilangnya pelepasan insulin fasepertama sehingga lonjakan awal insulin postprandial tidak terjadi pada lansia dengan DM, peningkatan kadar glukosa postprandial dengan kadar glukosa puasa normal.

DM pada lansia umumnya bersifat asimptomatik. Walaupun ada gejala, seringkali berupa gejala tidak khas seperti kelemahan, letargi, perubahan tingkah laku, menurunnya status kognitif atau kemampuan fungsional (antara lain delirium, demensia, depresi, agitasi, mudah jatuh, dan inkontinensia urin). Inilah yang menyebabkan diagnosis DM pada lansia seringkali agak terlambat (Sclatter, 2003). Bahkan, DM pada lansia seringkali baru terdiagnosis setelah timbul penyakit lain. Berikut adalah data mengenai manifestasi klinis pasien lansia sebelum diagnosis DM ditegakkan (Burduli, 2009).

Pada usia75 tahun, diperkirakan sekitar 20\% lansia mengalami DM, dan kurang lebih setengahnya tidak menyadari adanya penyakit ini. Oleh sebab itu, American Diabetes Association (ADA) menganjurkan penapisan (skrining) DM sebaiknya dilakukan terhadaap orang yang berusia 45 tahun ke atas dengan interval 3 tahun sekali. Interval ini dapat lebih pendek pada pasien berisiko tinggi terutama dengan hipertensi dan dislipedemia (Kane, 2009).

Berikut ini adalah kriteria diagnosis DM menurut standar pelayanan medis ADA 2010.

Kriteria Diagnosis DM :

1. $\mathrm{HbA} 1 \mathrm{C} \geq 6,5 \%$; atau

2. Kadar gula darah puasa $\geq 126 \mathrm{mg} / \mathrm{dL}$; atau

3. Kadar gula darah 2 jam $\mathrm{pp} \geq 200 \mathrm{mg} / \mathrm{dL}$ pada tes toleransi glukosa oral yang dilakukan dengan 75 g glukosa standar WHO

4. Pasien dengan gejala klasik hiperglikemia atau krisis hiperglikemia dengan kadar gula sewaktu $\geq 200 \mathrm{mg} / \mathrm{dL}$

Panduan: American Diabetes Association (2010)

\section{Asam Urat}

Pada lansia terjadi kemunduran sel-sel karena proses penuaan yang dapat berakibat pada kelemahan organ, kemunduran fisik, timbulnya berbagai macam penyakit seperti peningkatan kadar asam urat yang dapat menimbulkan terjadinya penyakit seperti batu ginjal, gout, dan rematik (Efendi dan Makhfudi, 2009). Penyakit asam urat atau biasa 
dikenal dengan gout merupakan penyakit yang menyerang para lansia terutama kaum pria. Penyakit ini sering menyebabkan gangguan pada satu sendi misalnya paling sering pada salah satu pangkal ibu jari kaki, walaupun dapat menyerang lebih dari satu sendi. Penyakit ini sering menyerang para lansia dan jarang didapati pada orang yang berusia di bawah 60 tahun, dengan usia rata-rata paling banyak didapati pada usia 65-75 tahun, dan semakin sering didapati seiring bertambahnya usia (Kertia, 2009).

Asam urat adalah produk akhir atau produk buangan yang dihasilkan dari metabolisme/pemecahan urin. Asam urat sebenarnya merupakan antioksidan dari manusia dan hewan, tetapi bila dalam jumlah berlebihan dalam darah akan mengalami pengkristalan dan dapat menimbulkan gout. Asam urat mempunyai peran sebagai antioksidan bila kadarnya tidak berlebihan dalam darah, namun bila kadarnya berlebih asam urat akan berperan sebagai prooksidan (Francis, 2000).

Kadar asam urat dapat diketahui melalui hasil pemeriksaan darah dan urin. Nilai rujukan kadar asam urat darah normal pada laki-laki yaitu 3,6-8,2 mg/dL, sedangkan pada perempuan yaitu 2,3-6,1 mg/dL (Francis, 2000). Pembentukan asam urat dalam darah juga dapat meningkat disebabkan oleh faktor luar, terutama makanan dan minuman yang merangsang pembentukan asam urat. Adanya gangguan dalam proses ekskresi dalam tubuh jug akan menyebabkan penumpukan asam urat di dalam ginjal dan persendian.

Beberapa hal di bawah ini menyebabkan peningkatan kadar asam urat dalam tubuh :

- Kandungan makanan tinggi purin karena meningkatkan produk asam urat dan kandungan minuman tinggi fruktosa.

- Ekskresi asam urat berkurang karena fungsi ginjal terganggu, misalnya kegagalan fungsi glomerulus atau adanya obstruksi sehingga kadar asam urat dalam darah meningkat. Kondisi ini disebut hiperuricemia, dan dapat membentuk kristal asam urat/batu ginjal yang akan menyebabkan sumbatan pada ureter (Mandell, 2008).

- Penyakit tertentu seperti gout, Lesch-Nyhan syndrome, endogenous nucleic acidmetabolism, kanker, kadar abnormal eritrosit dalam darah karena destruksi sel darah merah, polisitemia, anemia pernisiosa, leukemia, gangguan genetik metabolisme purin, gangguan metabolik asam urat bawaan (peningkatan sintesis asam urat endogen), alkoholisme yang meningkatkan laktikasidemia, hipertrigliseridemia, gangguan pda fungsi ginjal dan obesitas, asidosis ketotik, asidosis laktat, ketoasidosis, laktosidosis, dan psoriasis (Murray et al., 2006).

- Beberapa macam obat sepertti obat diuretika golongan tiazid, asetosal dosis rendah, fenilbutazon dan pirazinamiddapat meningkatkan ekskresi cairan tubuh, namun menurunkan sekresi asam urat pada tubulus ginjal, sehingga terjadi peningkatan kadar asam urat dalam darah (Lieberman dan Marks, 2009).

- Pada pemakaian hormonal untuk terapi seperti hormon adrenokortikotropik dan kortikosteroid (Ronco dan Rodeghiero, 2005).

Hiperuricemia tidak selalu tampak dari gejala luar. Hal demikian mempunyai risiko besar untuk menjadi kerusakan ginjal karena kristal sudah mengendap di jaringan kemih. 
Seseorang dikatakan hiperuricemi apabila pada pemeriksaan laboratorium kadar asam urat darahnya di atas $7 \mathrm{mg} / \mathrm{dL}$ untuk pria, dan $6 \mathrm{mg} / \mathrm{dL}$ untuk wanita (Sacher et al., 2004).Kadar asamurat darah yang tinggi dapat menyebabkan kesemutan, pegal-pegal, linu, kaku pada persendian, nyeri sendi, sampai penyakit jantung dan tekana darah tinggi. Rasa ngilu biasnya dirasakan di kaki kanan dan tangan kiri. Jika sudah menyerang tangan kiri, rasa ngilu akan terus merambat ke bahu dan leher (Kertia, 2009).

\section{Kolesterol}

Kolesterol merupakan salah satu jenis lemak yang diproduksi oleh hati dan sangat diperlukan oleh tubuh. Tetapi kolesterol berlebih akan menimbulkan masalah, terutama pada pembuluh darah jantung dan otak. Setiap orang memiliki kolesterol di dalam darahnya, dimana 50\% diproduksi oleh tubuh sendiri dan sisanya berasal dari makanan. Kolesterol yang diproduksi terdiri atas 2 jenis, yaitu HDL dan LDL. Kolesterol tidak hanya menjadi komponen penting dari dinding sel, tapi juga penting untuk produksi hormon tertentu. Bagi kebanyakan orang, 70-75\% kolesterol dalam darah diproduksi oleh sel hati mereka, 25-30\% lainnya berasal dari makanan yang dimakan (Santoso, 2011).

Hiperkolesterolemia adalah peningkatan kadar kolesterol di dalam darah. Kadar kolesterol darah yang tinggi merupakan masalah yang serius karena merupakan salah satu faktor risiko yang paling utama untuk terjadinya penyakit jantung koroner (PJK) di samping faktor lainnya, yaitu tekanan darah tinggi dan merokok. Karena kadar kolesterol yang tinggi dapat mengganggu kesehatan bahkan mengancam kehidupan manusia, maka perlu kiranya dilakukan penanggulangan untuk menurunkan kadar kolesterol darah. Salah satu usaha yang paling baik adalah menjaga agar makanan yang kita makan sehari-hari rendah kolesterol (Baraas, 2003).

Kadar Kolesterol Total :

\begin{tabular}{ll}
\hline Normal & $<200 \mathrm{mg} / \mathrm{dL}$ \\
Agak Tinggi (pertengahan) & $200-239 \mathrm{mg} / \mathrm{dL}$ \\
Tinggi & $>240 \mathrm{mg} / \mathrm{dL}$ \\
\hline
\end{tabular}

(Santoso, 2011)

Kolesterol, lemak, dan substansi lainnya dapat menyebabkan penebalan dinding pembuluh darah arteri, sehingga lubang pembuluh darah tersebut menyempit; proses ini disebut aterosklerosis. Penyempitan pembuluh darah koroner yang fungsinya memberi oksigen ke jantung menjadi berkurang. Kurangnya oksigen ini akan menyebabkan otot jantung menjadi lemah, nyeri dada, serangan jantung, bahkan kematian (Baraas, 2003).

Makanan sehari-hari dapat meningkatkan ataupun menurunkan kadar kolesterol darah. Makanan orang Amerika rata-rata mengandung lemak jenuh dan kolesterol yang tinggi seperti daging yang berlemak, susu, es krim, telur, makanan gorengan, kue kering, dan cake yang biasanya akan meningkatkan kadar kolesterol darah. Sedangkan makanan orang Jepang umumnya berupa nasi, sayur-sayuran, buah-buahan, dan ikan sehingga orang Jepang rata-rata mempunyai kadar kolesterol yang rendah. Jadi, diet atau susunan makanan 
merupakan faktor penting yang mempengaruhi tinggi rendahnya kolesterol darah (Bull et al., 2007).

Di samping itu, faktor keturunan, jenis kelamin, umur, kegemukan, stress, alkohol, dan aktivitas juga dapat mempengaruhi kadar kolesterol darah. Pada lansia, terjadi penurunan aliran darah ke hati sampai 35\% (Tamher dan Noorkasiani. 2009). Terjadi proporsi lemak empedu tanpa diikuti perubahan metabolisme asam empedu yang signifikan. Implikasi dari hal ini adalah peningkatan sekresi kolesterol (Stanley dan Beare, 2006).

\section{Tujuan dan Manfaat}

Kegiatan ini bertujuan untuk mensosialisasikan kembali pentingnya pemeriksaan kesehatan lansia, misalnya pemeriksaan gula darah, asamurat, dan kolesterol secara berkala, dengan harapan dapat mendeteksi lebih dini masalah-masalah kesehatan yang mungkin ditimbulkan oleh kelainan pada kondisi tersebut. Lebih lanjut untuk meminimalisir terjadinya komplikasi dan timbulnya disabilitas akibat penanganan yang terlambat.Dari kegiatan ini diharapkan peserta dapat mengetahui kadar gula, asam urat, dan kolesterol darahnya, serta dapat diatasi dengan segera apabila ditemukan masalah.

\section{METODE PENGABDIAN}

Pada kegiatan ini dilakukan pemeriksaan kadar gula, asam urat, dan kolesteol darah menggunakan alat ukur GCU-meter dengan mengambil darah perifer di ujung jari sebagai sampel pemeriksaannya. Setelah diperiksa, peserta dipersilakan untuk berkonsultasi dengan dokter yang bertugas, dan selanjutnya diberikan obat sesuai dengan keluhan dan masalah kesehatan yang dialami.

\section{HASIL DAN PEMBAHASAN}

Peserta yang mengikuti kegiatan sejumlah 100 orang, dengan berbagai masalah kesehatan yang dialaminya. Dari hasil pemeriksaan pada peserta, didapatkan data sejumlah 53 orang peserta memiliki kadar gula darah di atas normal (hiperglikemia), 24 orang dengan kadar asam urat darah di atas normal (hiperuricemia), dan 59 orang peserta dengan kadar kolesterol di atas normal (hiperlipidemia). Hasil tersebut dapat memberikan gambaran tentang kondisi lansia yang sebagian besar mengalami kemunduran fungsi fisiologis tubuhnya, sehingga memberikan implikasi berupa penyakit degeneratif tersebut. Diharapkan hasil pemeriksaan ini dapat menjadi acuan bagi peserta maupun tenaga kesehatan khususnya dokter untuk menentukan rencana terapi maupun tindakan pencegahan lainnya, terutama berupa pemeriksaan kesehatan yang rutin dan berkala. 
Kegiatan pengabdian yang dilakukan pada hari Minggu, 10 Agustus 2014 di Klinik Pratama Asy Syifa Kota Bengkulu ini berjalan cukup baik dan sesuai dengan rencana. Acara dimulai pukul 08.00 dan diakhiri pukul 12.00 WIB. Peserta yang hadir sesuai dengan target, yaitu 100 orang. Tidak ada kendala yang cukup berarti selama berlangsungnya kegiatan. Para peserta tampak antusias dan bersemangat menjalani pemeriksaan dan berkonsultasi dengan dokter. Diharapkan setelah mengikuti kegiatan ini peserta dapat lebih menyadari pentingnya memeriksakan kesehatannya secara berkala untuk mengurangi angka kesakitan akibat penyakit degeneratif dan masalah kesehatan lain yang tidak terdiagnosis dengan tepat.

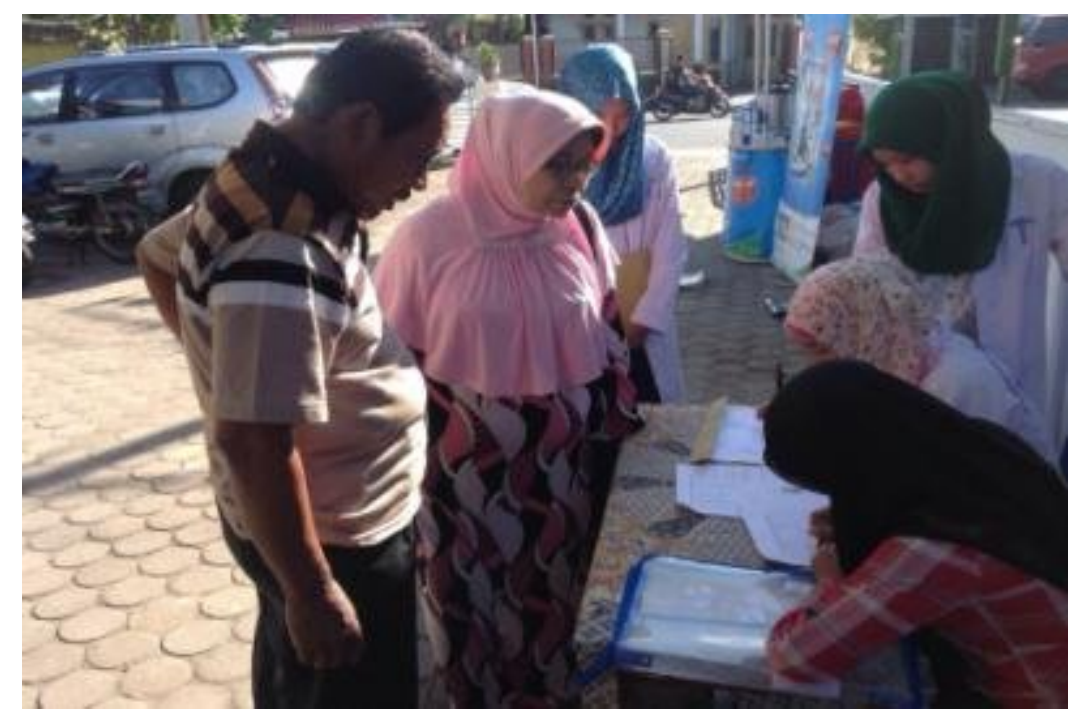

Gambar 1. Peserta Melakukan Registrasi

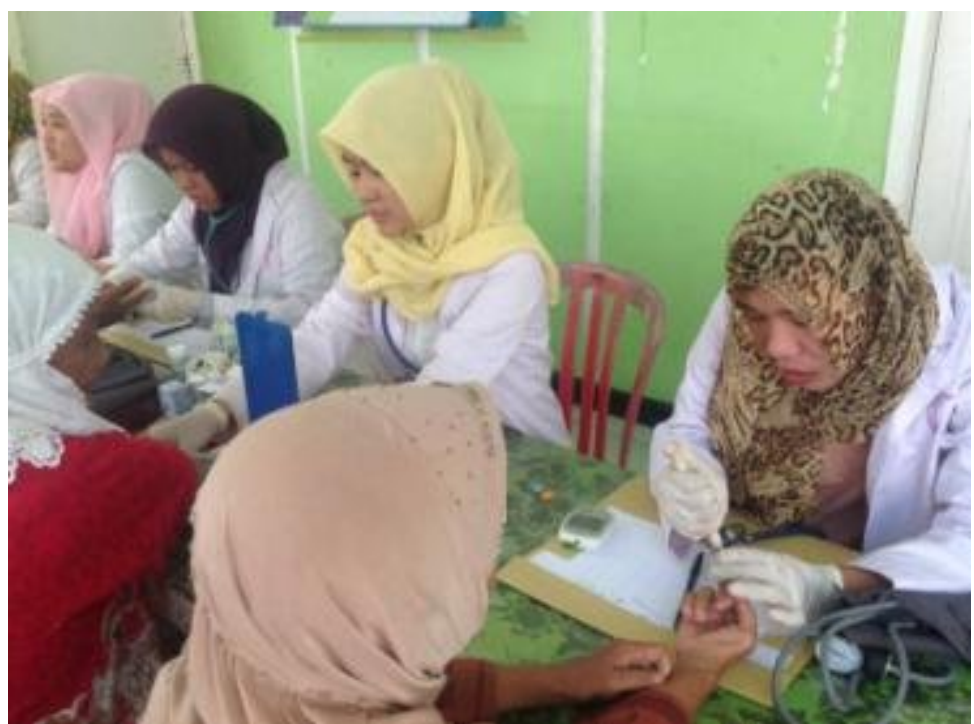

Gambar 2. Pemeriksaan Kadar Gula, Asam Urat, dan Kolesterol Darah 


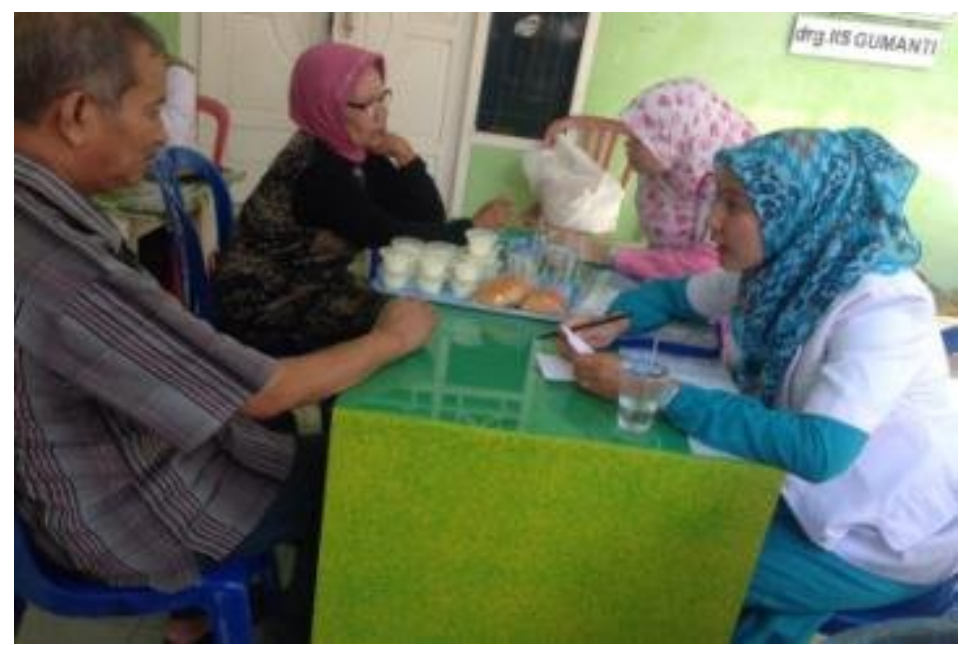

Gambar 3. Konsultasi dengan Dokter Pelaksana

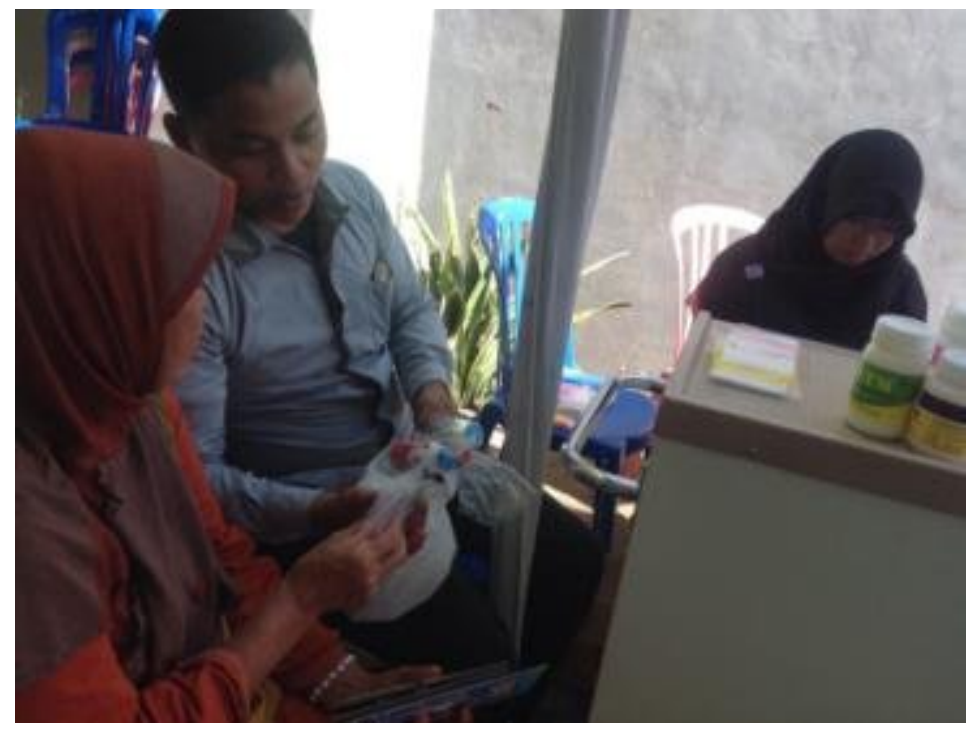

Gambar 4. Pemberian Obat dan Bingkisan untuk Peserta 


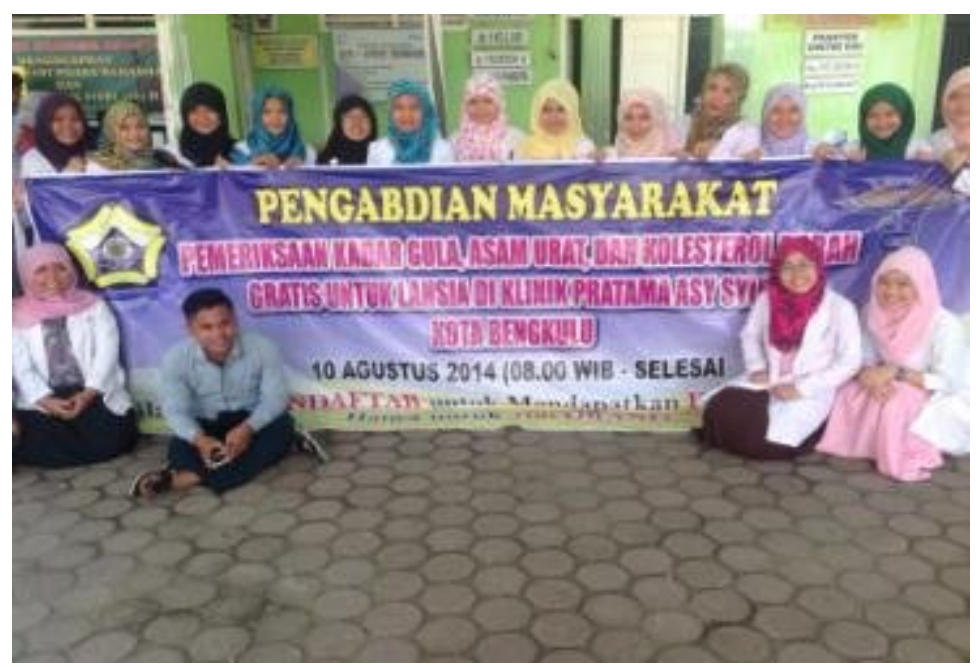

Gambar 5. Panitia Pelaksana

\section{KESIMPULAN DAN SARAN}

\section{Kesimpulan}

Dari hasil pemeriksaan pada peserta, didapatkan data sejumlah 53 orang peserta memiliki kadar gula darah di atas normal (hiperglikemia), 24 orang dengan kadar asam urat darah di atas normal (hiperuricemia), dan 59 orang peserta dengan kadar kolesterol di atas normal (hiperlipidemia).

\section{Saran}

1. Bagi Universitas, agar dapat berkelanjutan mendukung kegiatan pengabdian ini sehingga dapat memberikan manfaat bagi masyarakat umum.

2. Bagi LPPM, untuk dicoba dikaitkan dengan bidang lain supaya lebih terintegrasi dan terevaluasi sehingga bisa menjadi program rutin di Universitas Bengkulu.

3. Bagi peserta, agar membiasakan diri untuk memeriksakan kesehatannya secara berkala.

\section{DAFTAR PUSTAKA}

American Diabetes Association, 2010, Standarsdof Medical Care in Diabetes, ADA, USA. Baraas, F., 2003, Mencegah Serangan Jantung dengan Menekan Kolesterol, Yayasan Kardia Iqratama, Jakarta.

Bull, Eleanor dan Morrell, 2007, Kolesteroli, Erlangga, Jakarta.

Burduli, M., 2009, The Adequate Control of Type 2 Diabetes Mellitus in an Elderly Age http://www.gestosis.ge/eng/pdf_09/Mary_Burduli.pdf., 10 Maret 2014.

Depkes, 2007, Materi Rakernas, Depkes RI, Jakarta. 
Darmojo, B., 2009, Buku Ajar Geriatri: Teori Proses Menua, Edisi Ke-4, Balai Penerbit FKUI, Jakarta.

Effendi F. dan Makhfudli, 2009, Keperawatan Kesehatan Komunitas: Teori dan Praktik dalam Keperawatan, Salemba Medika, Jakarta.

Francis, H. M., 2000, Uric Acid, Terjemahan Suseno Akbar, Salemba Medika, Jakarta.

Kane, R.L., Ouslander J.G., Abras R.B., Resnick B., 2009, Essentials of Clinical

Geriatrics, Edisi Keenam, McGraw Hill, New York.

Kertia, Nyoman, 2009, Asam Urat, Kartika Media, Yogyakarta.

Lieberman M., Marks A.D., 2009, Basic Medical Biochemistry: a Clinical Approach, Edisi Ketiga, Lippincott Williams \& Wilkins, Philadelpia.

Mandell, B. F., 2008, Cleveland Clinic Journal of Medicine: Clinical Manifestasions of Hyperuricemia and Gout, Department of Rheumatic and Immunologic Diseases,

Center for Vasculitis Care and Research, Cleveland Clinic, Cleveland.

Murray R. K., Granner D. K., Rodwell V. W., 2006, Harper's Illustrated Biochemistry,

Edisi Ke-27, McGraw Hill, Boston.

Rochmah, W., 2007, Buku Ajar Ilmu Penyakit Dalam: Diabetes Mellitus pada Usia Lanjut, Edisi Keempat, Pusat Penerbitan IPD FKUI, Jakarta.

Ronco C., Franscesco R., 2005, Hyperuricemic Syndromes: Pathophysiology and Therapy Vo. 147, Karger, New York.

Sacher, Ronald A., Richard A. M., 2004, Tinjauan Klinis hasil Pemeriksaan

Laboratorium, Edisi Ke-11, Terjemahan Brahm U. Pendit dan Dewi Wulandari, EGC, Jakarta.

Santoso, Soegeng, dkk., 1999, Kesehatan dan Gizi, Rineka Cipta, Jakarta.

Sclatter, A., 2003, Diabetes in the Erderly: The Geriatrician's Perspective, http://www.diabetes.ca/files/ElderlySclatterjune03.pdf., 10 Maret 2014.

Stanley M. dan P. G. Beare, 2006, Buku Ajar Keperawatan Gerontik, Edisi Kedua, EGC, Jakarta.

Subramaniam, I., 2005, Diabetes Mellitus in Elderly, http://www.jiag.org/sept/diabetes.pdf., 10 Maret 2014.

Tamher dan Noorkasiani, 2009, Kesehatan Usia Lanjut dengan Pendekatan Asuhan Keperawatan, Salemba Medika, Jakarta. 